\title{
Effect Of Theophylline On Blood Pressure Of Normotensive Cats Pre-Administered With Adrenaline.
}

\author{
Isa, A.I. ${ }^{1}$, Felix, S. Y. ${ }^{1}$, Saleh, M.I.A. ${ }^{1}$, Muhammad, A. ${ }^{1}$, Mohammed, A. ${ }^{1}$, \\ Mohammed, K.A. and Bako, I.G \\ Department of Human Physiology, Faculty of Medicine, Ahmadu Bello University, Zaria, Nigeria.
}

\begin{abstract}
The effect of various volumes of theophylline (Aminophylline) $(4 \mathrm{mg} / \mathrm{kg}$ ) on the blood pressure of normotensive cats pre-administered with adrenaline was determined. The results obtained revealed that theophylline showed a potentiating effect $(p<0.05)$ oncatecolamines (adrenaline $(10 \mu \mathrm{g} / \mathrm{ml})$ in elevating the systolic, diastolic and mean arterial blood pressure of the normotensive cats. Although, theophylline alone caused an increase $(p<0.05)$ in the diastolic and mean arterial blood pressure which may be due to the increase sympathetic discharge by theophylline. The antagonistic test carried out reveals the attenuatic effect $(p<0.05)$ of the calcium channel blocker (nifedipine $2 \mathrm{mg} / \mathrm{ml}$ ) on the combination (adrenaline and theophylline). Theophylline posesses a potentiating effect on catecholamine in determining it effect on blood pressure of normotensive cats and it was inhibited by L-type calcium channel blocker (nifedipine).
\end{abstract}

Key words: Theophylline, accentuation, adrenaline, nifedipine, blood pressure.

\section{Introduction}

The arterial blood pressure is the lateral pressure exerted by the column of blood on the arterial wall [1]. The normal arterial blood pressure in the brachial artery for young adults at rest, in the sitting or lying position is approximately 120/80 mmHg. Above this level (at about 140/90) is regarded as hypertension, while below the average level (at about 90/60) is regarded as hypotension. The actual blood pressure of an individual can be concluded by measuring it at three consecutive days. It is appreciably lower at night and is lower in women than in men [2]. Sympathetic stimulation increases both propulsion by the heart and resistance to flow (by increasing the peripheral resistance), which usually causes the pressure to increase greatly [3]. Circulating adrenaline and noradrenaline have almost the same effects on the different organs as those caused by direct sympathetic stimulation [4]. Hypertension also known as high blood pressure has been a condition of chronically elevated systemic blood pressure. However, the World Health Organization (WHO) recommended considering cases as hypertension if the systolic pressure is higher than $160 \mathrm{mmHg}$ or the diastolic pressure is higher than $95 \mathrm{mmHg}$ in adult. Cases with systolic pressure between $140-160 \mathrm{mmHg}$ and diastolic pressure between $90-95 \mathrm{mmHg}$ are considered as borderline cases [1]. Theophylline is a methylxanthine from xanthine-containing herbs such as Camellia Sinensis (Tea), Coffea Arabica (coffee beans), Cola Nitada (kola), Ilex Paraguariensis (mat), PaulinaCapana (guarana) [5]. Other methylxanthines include caffeine and theobromine. Theophylline (a non-selective phosphodiesterase inhibitor) has much application commercially in Nigeria. It is used medically for the management of chronic obstructive pulmonary disease (COPD), asthma, infant apnea and as diuretic. The xanthines are infrequently used by herbalist as mild stimulant [6]. Also in combination withother beta adrenergic receptor sympathomimetics, Theophylline has been widely used in the management of respiratory diseases such as asthma and chronic obstructive pulmonary disease, this is due to the sympathomimetic effect of theophylline on the bronchial smooth muscle[7]. Theophylline has been used for the management of obstructive respiratory disorders such as Asthma and Obstructive pulmonary disease. But it's cardiovascular unfavourable side effect reduces it therapeutic usage [8].

The present study was designed to test the potentiating effect of theophylline on adrenaline in the blood pressure of normotensive cats.

\section{Materials And Methods}

2.1 ChemicalsUsed

All chemicals and drugs were obtained commercially and were of analytic grade.They are; Theophylline (in different volumes), Acetylcholine $(2 \mu \mathrm{g} / \mathrm{ml})$, Adrenaline $(10 \mu \mathrm{g} / \mathrm{ml})$, Nifedipine $(4 \mathrm{mg} / \mathrm{ml})$, Heparin solution, Normal saline solution, Thiopental sodium.

\subsection{Animals}

The animals chosen and used for this study were two male cats. The cats, each weighing $1.6 \mathrm{~kg}$ and $1.3 \mathrm{~kg}$ respectively, were brought to the laboratory from a domestic home with the consent of the owner (coupled 
with the diplomatic agreement of what the cats will be used for) and were of good health. The animals were housed in standard environmental condition of temperature $\left(21 \pm 2^{\circ}\right)$ till the day the experiment was carried out. Mercy killing was given to the used cats at the end of the experiment.

\subsection{Experimental Design}

In the experiment, the same procedure was carried out on both cats. Normal saline was used for the control reading.Different volumes of adrenaline were administered prior to the administration of different volumes of theophylline intravenously. In the antagonistic study,both drugs were administered prior to the administration of nifedipine intravenously. All these were done after the animals have been anaesthesized, whileheparine was used to flush each drug.

\subsection{Determination of Blood Pressure Levels}

The blood pressure values of the cat for normal saline (normal basal rhythm or control), and the administered with standard drugs (adrenaline) and acting agent (Theophylline) as well as results from the antagonistic studies as obtained from the microdynamometer are tabulated below. $1 \mathrm{~cm}$ of the standard ruler was used in measuring the systolic and diastolic blood pressure which corresponds to $10 \mathrm{mmHg}$ of pressure change in the mercury in glass sphygmomanometer.To determine the diastolic pressure on the tracing, the value from the baseline to the lowest border of the tracing was read while the systolic pressure was read from the baseline to upper convex curve of the tracing.

\subsection{Statistical Analysis}

Blood pressure tracing results were analyzed using SPSS (Statistical Package for Social Sciences)and represented as Mean, Standard Error of Mean $\pm(\mathrm{SEM})$ and percentage changes. The data collected were also analyzed using ANOVA while $\mathrm{p}<0.05$ were considered as significant[9].

\section{Results}

The blood pressure level of the normotensive cats after the intravenous infusion of theophylline $(4 \mathrm{mg} / \mathrm{kg})$ only is shown in table 3,4 and 5 . In relation to the blood pressure level caused by normal saline (control), theophylline caused a significant increase $(\mathrm{p}<0.05)$ in the diastolic and mean arterial blood pressure.

3.1 Tables and Figures of Result

Table1:Showing the systolic blood pressure, mean, standard error of mean and P-value of the cats for normal saline, acetylcholine and adrenaline. (All values in $\mathrm{mmHg}$ )

\begin{tabular}{|c|c|c|c|c|}
\hline & Volume(ml) & $\begin{array}{l}\text { Basal blood pressure } \\
\text { (normal saline } 0.9 \% \text { ) }\end{array}$ & $\begin{array}{c}\text { Acetylcholine } \\
(2 \mu \mathrm{g} / \mathrm{ml})\end{array}$ & $\begin{array}{c}\text { Adrenaline } \\
(10 \mu \mathrm{g} / \mathrm{ml})\end{array}$ \\
\hline & 0.1 & 63 & 42 & 63 \\
\hline & 0.2 & 66 & 40 & 74 \\
\hline & 0.4 & 67 & 32 & 85 \\
\hline & 0.8 & 69 & 27 & 87 \\
\hline & 1.0 & 66 & 28 & 84 \\
\hline Mean \pm SEM & & $66.20 \pm 0.77$ & $33.80 \pm 3.07$ & $78.60 \pm 4.56$ \\
\hline \multicolumn{2}{|c|}{ P-Value } & & (a) & (a) \\
\hline
\end{tabular}

$\mathrm{P}<0.05=$ significant $(\mathrm{a})$

Table.2:Showing the diastolic blood pressure, mean, standard error of mean and P-value of the cat for normal saline, acetylcholine and adrenaline. (All values in $\mathrm{mmHg}$ )

\begin{tabular}{|c|c|c|c|c|}
\hline & Volume(ml) & $\begin{array}{l}\text { Basal blood pressure } \\
\text { (normal saline } 0.9 \% \text { ) }\end{array}$ & $\begin{array}{c}\text { Acetylcholine } \\
2 \mu \mathrm{g} / \mathrm{ml}\end{array}$ & $\begin{array}{c}\text { Adrenaline } \\
(10 \mu \mathrm{g} / \mathrm{ml})\end{array}$ \\
\hline & 0.1 & 40 & 23 & 43 \\
\hline & 0.2 & 43 & 20 & 48 \\
\hline & 0.4 & 44 & 14 & 46 \\
\hline & 0.8 & 44 & 11 & 51 \\
\hline & 1.0 & 43 & 12 & 47 \\
\hline Mean \pm SEM & & $42.80 \pm 0.73$ & $16.00 \pm 2.34$ & $47.00 \pm 1.30$ \\
\hline P-Value & & & (a) & (a) \\
\hline
\end{tabular}

$\mathrm{P}<0.05=$ significant (a) 
Effect Of Theophylline On Blood Pressure Of Normotensive Cats Pre-Administered With Adrenaline.

Table3: Showing the systolic blood pressure, mean, standard error of mean and P-values of the cat for normal saline (control) and theophylline (acting agent). (All values in $\mathrm{mmHg}$ )

\begin{tabular}{cccc}
\hline & Volume $(\mathrm{ml})$ & $\begin{array}{c}\text { Basal blood pressure } \\
\text { (normal saline 0.9\%) }\end{array}$ & $\begin{array}{c}\text { Theophylline } \\
\text { 4mg/kg }\end{array}$ \\
\hline & 0.1 & 63 & 65 \\
& 0.2 & 66 & 71 \\
& 0.4 & 67 & 72 \\
Mean \pm SEM & 0.8 & 69 & 68 \\
P-Value & 1.0 & 66 & 68 \\
& & $66.20 \pm 0.97$ & $68.80 \pm 1.24$ \\
(ns)
\end{tabular}

$n s=$ not significant $(p>0.05)$

Table4: Showing the diastolic blood pressure, mean, standard error of mean and P-value of the cat for normal saline (control) and Theophylline (acting agent). (All values in $\mathrm{mmHg}$ ).

\begin{tabular}{cccc}
\hline & Volume $(\mathbf{m l})$ & $\begin{array}{c}\text { Basal blood pressure } \\
\text { (normal saline 0.9\%) }\end{array}$ & $\begin{array}{c}\text { Theophylline } \\
(\mathbf{4 m g} / \mathbf{k g})\end{array}$ \\
\hline 0.1 & 40 & 40 \\
& 0.2 & 43 & 44 \\
& 0.4 & 44 & 46 \\
Mean \pm SEM & 0.8 & 44 & 46 \\
P-Value & 1.0 & 43 & 46 \\
& & $42.80 \pm 0.73$ & $44.40 \pm 1.16$ \\
\hline
\end{tabular}

Table5: Showing the mean arterial blood, mean, standard error of mean and drug interaction of the cat for theophylline and adrenaline. (All values in $\mathrm{mmHg}$ ).

\begin{tabular}{|c|c|c|c|c|c|}
\hline & $\begin{array}{l}\text { Volume } \\
\text { (ml) }\end{array}$ & $\begin{array}{c}\text { Basal blood } \\
\text { pressure } \\
\text { (normal saline } \\
0.9 \%)\end{array}$ & $\begin{array}{c}\text { Adrenaline } \\
(10 \mu \mathrm{g} / \mathrm{ml})\end{array}$ & $\begin{array}{c}\text { Theophylline } \\
\text { (4mg/kg) }\end{array}$ & $\begin{array}{c}\text { Adrenaline }(10 \mu \mathrm{g} / \mathrm{ml}) \\
+ \\
\text { Theophylline }(4 \mathrm{mg} / \mathrm{kg})\end{array}$ \\
\hline & 0.1 & 47 & 50 & 52 & 56 \\
\hline & 0.2 & 51 & 56 & 55 & 56 \\
\hline & 0.4 & 51 & 59 & 57 & 62 \\
\hline & 0.8 & 52 & 63 & 56 & 63 \\
\hline & 1.0 & 51 & 59 & 55 & 62 \\
\hline \multirow[t]{2}{*}{ Mean+SEM } & & $50.40 \pm 0.87$ & $57.40 \pm 2.16$ & $55.00 \pm 0.84$ & $59.80 \pm 1.56$ \\
\hline & & & (a) & (a) & (a) \\
\hline
\end{tabular}

Table6: Showing the drug interaction and percentage changes. (All values in $\mathrm{mmHg}$ )

\begin{tabular}{|c|c|c|c|c|c|}
\hline $\begin{array}{c}\text { Drugs } \\
+ \\
\text { Acting agent }\end{array}$ & \multicolumn{3}{|c|}{$\begin{array}{c}\text { Adrenaline } 0.4 \mathrm{ml}(10 \mu \mathrm{g} / \mathrm{ml}) \\
+ \\
\text { Theophylline } 0.4 \mathrm{ml}(4 \mathrm{mg} / \mathrm{kg})\end{array}$} & \multicolumn{2}{|c|}{$\begin{array}{c}\text { Adrenaline } 0.4 \mathrm{ml}(10 \mu \mathrm{g} / \mathrm{ml}) \\
+ \\
\text { Theophylline } 0.4 \mathrm{ml}(4 \mathrm{mg} / \mathrm{kg}) \\
+ \\
\text { Nifedipine } 0.2 \mathrm{ml}(4 \mathrm{mg} / \mathrm{kg}) \\
\end{array}$} \\
\hline $\begin{array}{c}\text { Blood pressure } \\
\text { parameter }\end{array}$ & $\begin{array}{c}\text { Basal blood } \\
\text { pressure }\end{array}$ & $\begin{array}{c}\text { Adrenaline } \\
+ \\
\text { Theophylline }\end{array}$ & $\begin{array}{l}\text { Percentage } \\
\text { Change }(\%)\end{array}$ & $\begin{array}{c}\text { Adrenaline } \\
+ \\
\text { Theophylline } \\
+ \\
+ \\
\text { Nifedipine }\end{array}$ & $\begin{array}{l}\text { Percentage } \\
\text { Change } \\
(\%)\end{array}$ \\
\hline SBP & 67 & 78 & 14.1 & 57 & 26.92 \\
\hline DBP & 44 & 54 & 18.51 & 36 & 33.33 \\
\hline PP & 23 & 24 & 4.16 & 11 & 54.16 \\
\hline МАВР & 52 & 62 & 16.13 & 43 & 30.64 \\
\hline
\end{tabular}


Fig. 1 showing the systolic and diastolic blood pressure produced after administration of normal saline, adrenaline and theophylline

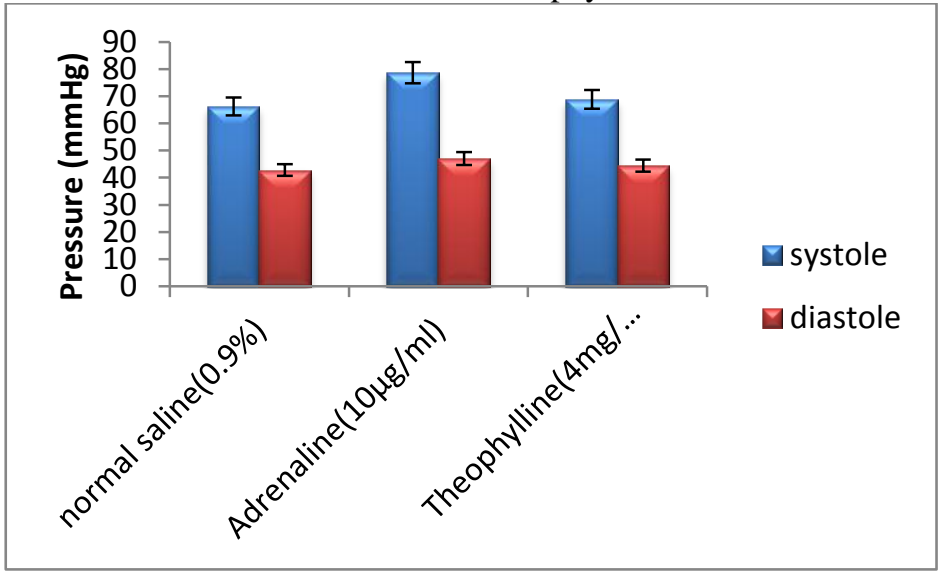

Fig. 2 showing the mean arterial blood pressure and pulse pressure produced after administration of normal saline, adrenaline and theophylline

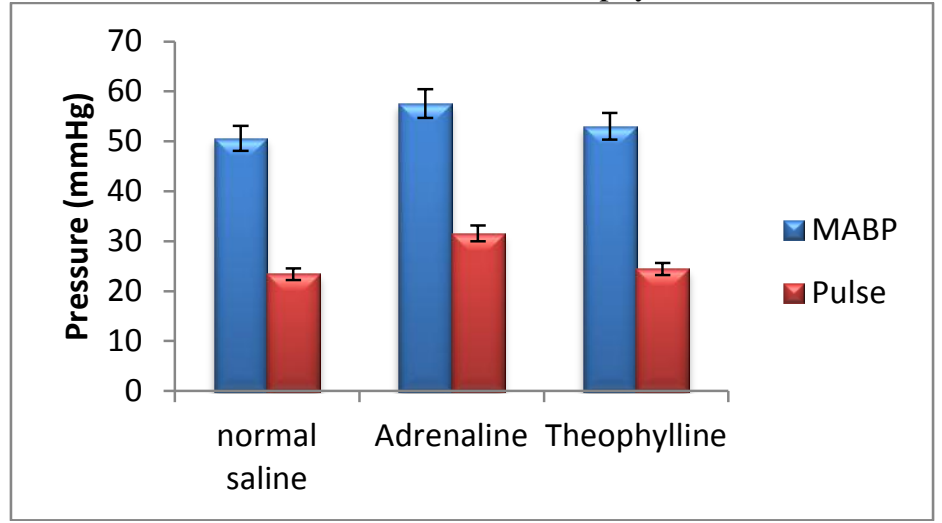

Fig. 3showing the systolic blood pressure, diastolic blood pressure, pulse pressure and mabp produced by the administration of theophylline and theophylline + adrenaline

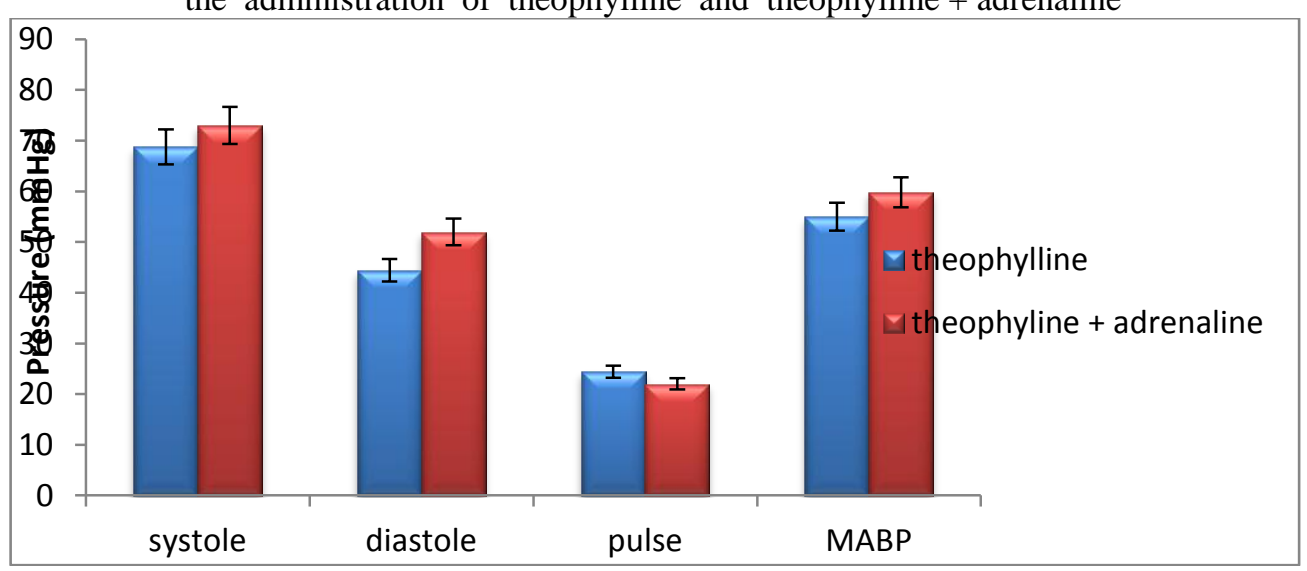

Fig. 4showing drug antagonistic studies (theophylline and adrenaline + nifedipine) 


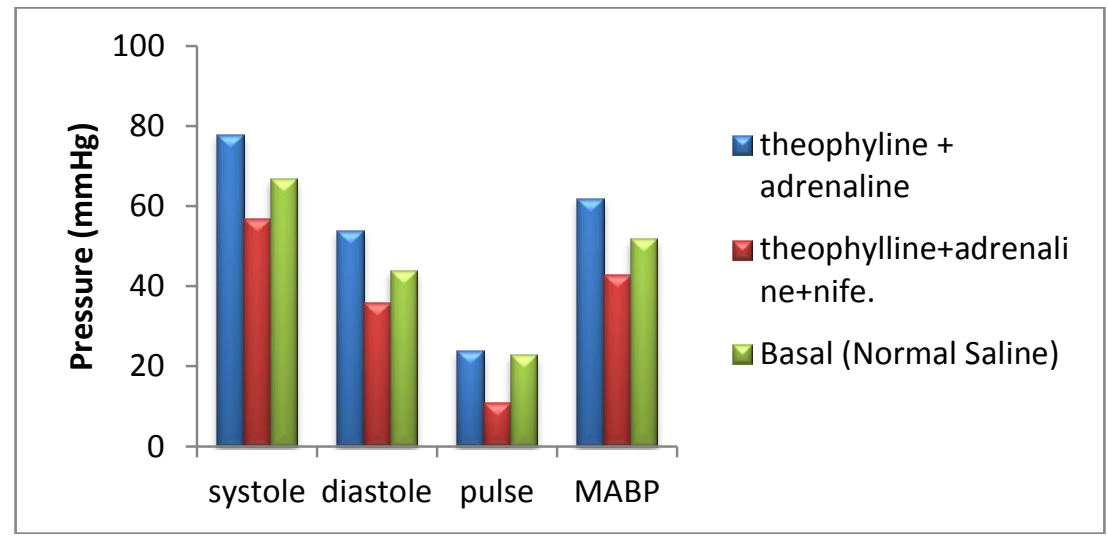

\section{Discussion}

The increased diastolic blood pressure may be due to increased muscle sympathetic nerve activity caused by theophylline which is in accordance with the findings of [3] and [10]. The increased diastolic blood pressure can no doubt alter the mean arterial blood pressure by causing an increase to it. Other studies postulated; Theophylline produced a 7\% increase in mean arterial blood which was not attenuated by beta blocker (propranolol) [11].Similarly, the observed significant increase in Mean arterial blood pressure of the normotensive cats, and the significant increase in systolic blood pressure might be due to the phosphodiesterase inhibitory effect of theophylline [12]. Also, the observation that nifedipine significantly reduced all the blood pressure parameters, such as; the systolic blood pressure (27\%), diastolic blood pressure (33\%) and mean arterial blood pressure (31\%), is in line with the fact thatNifedipine (L-type calcium channel blocker) reduces the intracellular concentration of depolarizing calcium ion [13].

\section{Conclusion}

In conclusion, the present study suggests therefore, that theophylline should be co-administered with a L-type calcium channel blocker in order to attenuate its unfavourable cardiovascular side effect.However, further investigation and elucidation should be carried out on isolated perfused heart.

\section{Acknowledgements}

The authors of this work wish to acknowledge the technical staff of Pharmacology laboratory, Department of Pharmacology, Faculty of Pharmaceutical Sciences, Ahmadu Bello University, Zaria, Nigeria. Also the technical staff of Department of Human Physiology, Faculty of Medicine, Ahmadu Bello University, Zaria, Nigeria for taking care of the animals.

\section{References}

[1]. A. Salah, and S. Adel, Physiology in Medical Practice (University Book Centre, Cairo, 2003).

[2]. W.F. Ganong, Cardiovascular regulatory mechanism, in Lange (Ed.) Review of medical physiology, 23 (San Francisco: Mc-Graw hill,San 2005) 31: 546-551.

[3]. L Lars, Differential effects of theophylline on sympathetic excitation, hemodynamics and breathing in congestive heart failure, European Journal of Pharmacology,110(2), 2004, 2157-2162.

[4]. A. Guyton, and J. Hall, Cardiovascular physiology, in E. Saunder (Ed.), Textbook of Medical Physiology, 12 (Pensylvania, Philadelpia: Elsevier Saunder Publisher, 2006) 240-244.

[5]. J. L Apgar, J.R. Tarka, and M. Stanly, Methylxanthine Composition and Consumption Patterns of Cocoa and Chocolate Products."In Gene A. Spiller Caffeine", CRC Press, 171, 1998.

[6]. E.O Bixler, A.N. Vgontzas, and H.M. Lin, Blood pressure associated with sleep-disordered breathing in a population sample of childern, American Journal of Physiology, 5 (1), 2008, 841-846.

[7]. K.F Rabe, H. Tenor, G. Dent, C. Schudt, S. Liebig, and H. Magnussen, Phosphodiesteraseisoenzyme modulation, American Journal of Physiology,264(5), 1995, 458-464.

[8]. J.B.Peter, Theophylline in chronic obstructive pulmonary disease, American Thoracic Society, 4(1), 2005, $334-339$.

[9]. R.C. Duncan, R.G. Knapp, and M.C. Miller, Test of hypothesis in population means, in J. Wiley (Ed.), Introductory biostatistic for health sciences, 1 (New York:John Wiley and sons Inc., 1977) 71-96

[10]. R Corti, C. Binggeli, and I. Sudano, Coffee acutely increases sympathetic nerve activity and Blood Pressure independently of caffeine content, Circulation, 106(4), 2002, 2935-2940.

[11]. E.H Prosnitz, and K.A. Conrad, Cardiovascular effect of theophylline, European Journal of Clinical Pharmacology, 24(3), 2007, 79-89.

[12]. S.H Richard, Cardiovascular effect of phosphodiesterase inhibitors, British Journal of Pharmacology, 39(10), 2011, 2016-2117.

[13]. S. Magdi, Human Physiology for Medical Students (University Book Centre, Cario, 2006). 